\title{
STUDY ON MANAGEMENT AND PRODUCTION SYSTEM OF SMALL SCALE DAIRY FARM IN A SELECTIVE RURAL AREA OF BANGLADESH
}

\author{
A B M K I Khan ${ }^{1}$, M A Baset ${ }^{2}$ and S K Fouzder ${ }^{3}$
}

\begin{abstract}
The present study was conducted to determine the present status including general information, feeding, breeding, housing, and milking etc. and costs \& returns of small dairy farms, to compare the productive and reproductive performance of crossbred and indigenous cows and to make recommendation for development of small scales dairy farm. With this view, the empirical data were collected by using pre tested questionnaire. The study was conducted at 8 thanas in Mymensingh district, and four months-long survey was diminished on thirty small dairy owners. It appeared from the study that $57 \%$ farm owners belong to business class and remaining 43 per cent to different categories. Fifty three per cent took dairying as a side-business whereas only 47 per cent took it as a main business enterprise. Major percentage of farm owner education level that was Higher Secondary level (60\%) and the average number of animal per farm was 13.01 . The average monthly income of farm owners found in the study area was Tk. 4387. It was observed that farm owners had $85.4 \%$ crossbred (like Friesian cross and Jersey cross) and was 14.6\% indigenous cattle, and $87 \%$ farmers used artificial insemination and rest used both artificial and natural services. Daily milk yield/cow/farm was 4.27 and 1.78 liters for a crossbred and indigenous dairy cow, respectively. It was estimated that the rearing cost of dairy cow was Tk. 67.5/cow/day and return from rearing dairy cow was Tk. 85.2/cow/day. The net return was Tk. 17.7/cow/day from crossbred in the study area and cost benefit ratio was 1: 1.26. The study showed that there were significant $(\mathrm{P}<0.01)$ differences within the dry period, service per conception, calving to first service, highest and lowest milk production and lactation period of crossbred and indigenous dairy cows. The study also showed non-significant differences within calving interval for crossbred and indigenous. Incase of small dairy farming, the farms were facing a lot of problems such as scarcity of feeds and fodder, high price of concentrate and lack of technical knowledge. Although the dairy cow owners face problems, the study observed that there were potentials particularly for the small dairy farmers. The small farmers by keeping 8-10 crossbred cows could earn a modest living by adopting small dairy farming as a profession
\end{abstract}

Key words: Cost and return, crossbred, dairy farming, indigenous, performance

\section{INTRODUCTION}

Cattle population in Bangladesh is about 24.13 million (FAO, 1994). In the rural area, cattle are kept mainly for draught purpose. Only a limited number of farmers have cow for milk production. Maximum cattle are nondescriptive type, which do not belong to any specific breed and termed as indigenous cattle. These animals are kept mainly in the stall with limited grazing on the roadside, embankment slope, fallow land and paddy straw are their staple food. Husbandry practices and health care of these animals are poor (Jabbar and Raha, 1984). The average milk production of local cows is very low and it varies between 300 to 400 liters per lactation period of 180 to 240 days. Such low productivity of indigenous cows is an important constraint for future development of the livestock sector. High productive exotic breeds and their crosses normally do not have adequate resistance against the prevalent diseases. They do not thrive well in our environment. In spite of all these problems, some people have shown interest for development of small dairy farms. Generally crossbred cows under village condition yields 600 to 800 liters if milk per lactation of 210 to 240 days (Islam, 1992).

\footnotetext{
${ }_{1}^{1}$ Animal Nutritionist cum Senior Instructor, Youth Training centre, Jamalpur, Bangladesh

${ }^{2}$ Associate professor, Department of Animal Nutrition and Livestock Management, Sylhet Agricultural University

${ }^{3}$ Assistant Professor, Department of Dairy and Poultry Science, Potuakhali University of Science and Technology
} 
Bangladesh suffers from an acute shortage of livestock products like milk, meat and eggs. The domestic demand for milk has been rising faster than the domestic production of milk. Hence Bangladesh Government has given the priority on the development of dairying at farmers level to increase the supply of milk from small dairy farms.

In Mymensingh district area, small and large scale dairy farms have been increasing day by day. Specially low income group of people has taken this farming as profitable enterprise. In order to establish future plan for dairy development in this region, it is essential to know details about the management practices and performances of different types of dairy breeds. Thus the study was undertaken with the following objectives:

i) To estimate the existing status regarding breeding, feeding, housing, milking, marketing of milk and management aspects of small dairy farms.

ii) To compare the productive and reproductive performances of crossbred and indigenous cows reared in small dairy farms.

iii) To calculate the costs and returns of small dairy farms.

\section{MATERIALS AND METHODS}

The study was conducted at the eight thanas (namely Mymensingh sadar, Phulpur, Haluaghat, Valuka, Trishal, Fulbaria, Muktagasha and Gauripur) of Mymensingh district in Bangladesh. Data were collected by a designed survey schedule according to objectives from April to July, 2002. The survey schedule was prepared based on the following key items: owner's general information, cattle population, sources of fund, housing system, feeds and feeding system, breeding system, over all management system, costs and returns of raising dairy cows, problems in dairying etc. A total of thirty (30) small dairy farms out of which 9 from sadar thana and 3 from each of the rest 7 thanas were randomly surveyed for this purposes. The data regarding productive and reproductive parameters of 112 crossbred cows and 19 indigenous dairy cows were collected. Data were collected through direct interviews and personal visits to the farm of selected farmers. Before beginning the interview, each respondent was given a brief description about the nature and purpose of the study. Responses of farmers were recorded directly on the interview schedules. Collected data from the farmers were compiled and tabulated. Tabulated data were arranged as percent value. The data regarding productive and reproductive performance were analyzed by the CRD described by Steel and Torrie (1980).

\section{RESULTS AND DISCUSSION}

\section{General information of small dairy farm owners}

The general information of dairy farm owners in Mymensingh district are presented in Table 1 . The results showed that the highest percentage $(57 \%)$ of the farmers had business as the principal occupation and the rest job seekers, agriculture etc. It was observed that $53 \%$ of the farmers had taken dairying as a main business and the rest as side business. Highest percentage (60\%) of the farmers had higher secondary level education and nobody was found illiterate and under secondary education level. Kabir (1995) conducted an economic study and found that the average literacy rate of farm house holds in all farm categories was also sufficiently higher than the national average. More than $76 \%$ house numbers of family in all the farm categories had above primary level of education. The crossbred farm owners had relatively higher level of education. Farmers were further categorized based on land owner. The highest percentage (57\%) of farmers posses 1-2 acres of land and lowest percentage (7\%) of farmers posses $0.5-1$ acres of land. It was found that $16.7 \%$ farmers had training on dairy farms and $83.3 \%$ farms had no training on dairy farm management. For establishing dairy farms, $7 \%$ of dairy farmers were dependent on bank loan, $10 \%$ on their own sources and $83 \%$ on bank loan and own source. The average capital investment was Tk. 45,000 to 2,50,000. 
It was observed that the highest number of farm 9 and 14 was in 4-8 and 9-15 herd size respectively. Khan (1996) conducted a study in different districts and found that out of 100 farms 45 farms had 4-8 herd size and only two farms had above 30 herd size. It was revealed

that monthly income of the owners were $0-2$ thousand, 2-4 thousand, 4-6 thousand and above 6 thousands taka for 20, 43, 13 and 20 per cent, respectively.

\section{Number of dairy cattle}

The dairy farms under study area consisted of different types of cattle, the percentage of which is present in Table 2. It was observed that the percentages of milch indigenous and crossbred cows were 14.6 and 83.4 respectively and the average numbers of cows in the farms were 1.89 and 11.1 for indigenous and crossbreed, respectively.

\section{Housing management}

Only 10 percent of the farmers provide half building and rest $90 \%$ of the farmers used tin shed and straw shed to house their cattle (Table 3). Highest percentage of farmers (80\%) provided open house, $13 \%$ provided closed and rest used semi-closed house. On the basis of floor type, $65 \%$ of farmhouse was found with pacca (with bricks) and the rest had unpaved floor. In another region of the same district, Hossain et al. (2004) observed that 63\% farmers provided closed house and 63\% farmers used paved floor.

Feeding management: There were two systems of feeding, which are practiced by the dairy owners to feed their cattle. Sixty three percent farmers followed stallfeeding and 37\% farmers followed both stall and grazing system (Table 3). All calves were fed milk by suckling. No farmer was found using bottle to provide milk to calves. The main livestock feed at the study area was rice straw. Most of the farmers (80\%) used untreated straw. It was noted that $20 \%$ and $40 \%$ farmers cultivated napier and maize, respectively and rest of the farmers did not cultivate fodder. Most important constraints regarding fodder cultivation are scarcity of land, scarcity of seed/cutting and lack of knowledge.

\section{Breeding system}

It was observed that $87 \%$ cows were inseminated artificially and $13 \%$ both naturally and artificially (Table 3) which is similar to the observation by Hossain et al. (2004), who found 93\% cows were inseminated artificially. For artificial insemination, the majority of the farmers preferred Friesian semen.

\section{Table 1: General information ofdairy farm owners}

\begin{tabular}{lcc}
\hline Variables & No. of farms & Percentage (\%) \\
\hline Owner's occupation & 2 & 7 \\
Service holder & 17 & 57 \\
Business & 5 & 17 \\
Job seeker & 3 & 10 \\
Agriculture & 3 & 9 \\
Others & & \\
Dairy farming & 16 & 53 \\
Main business & 14 & 47 \\
Side business & & \\
Education & 3 & 10 \\
Class 6-10 & 5 & 17 \\
Secondary school level & 18 & 60 \\
Higher secondary level & 4 & 13 \\
Above higher secondary level & & 7 \\
Land size (acre) & 2 & \\
0-0.5 & &
\end{tabular}




\section{Training received}

\section{Source of fund}

$\begin{array}{lcc}\text { Bank loan } & 2 & 7 \\ \text { Own source } & 3 & 10 \\ \text { Both } & 25 & 83 \\ \text { Herd size (Number) } & & \\ 0-3 & 2 & 7 \\ 4-8 & 9 & 30 \\ 9-15 & 14 & 47 \\ 16-30 & 4 & 13 \\ \text { Above 30 } & 1 & 3 \\ \text { Monthly income (Thousand) } & & \\ 0-2 & 6 & 20 \\ 2-4 & 14 & 47 \\ 4-6 & 4 & 13 \\ \text { Above } & 6 & 20\end{array}$

Overall management system: It was observed that $100 \%$ farmers milked their cows manually. Most of the farmers (77\%) used traditional equipments and 53\% farmers milked their cows hygienically (Table 3). The source of water in most of the farms was direct water supply by local authority and the supply was adequate in $80 \%$ farms. Majority of the farmers cleaned their cattle house regularly with the help of pipe. During milking, normal water was used to wash the udder by $67 \%$ farmers.

Maximum farmers did not maintain preventive register to record the preventive or treatment status and did not keep their cattle isolated while sick. Only $17 \%$ farm owners stored milk by freezing. Few farmers (7\%) appointed skilled labors in their farms. Thirty percent owners disposed their milk by home delivery and 30\% farmers sold milk from their own selling center. Some farmers also sold their milk in local market, sweet makers and broker. Among the farmers, $73 \%$ sold out the cow dung to the owner of fish pond and agricultural land and others who use cow dung as fuel. In the study area, Veterinary Surgeon was available when needed. It was found that all farmers dewormed their cattle according to schedule, and most of the farmers did vaccination against important diseases to keep the cattle free from disease outbreak. Eighty percent of the farmers faced difficulties to get loan from bank.

\section{Productive and reproductive parameters of crossbred and indigenous cows}

Dry period: The average dry period for crossbred and indigenous cows was 98.5 and 140 days respectively (Table 4). There was a statistically significant variation $(\mathrm{P}<0.01)$ in the length of dry period of crossbred and indigenous cows. These results were in agreement with

Ali et al. (2000) and Nahar et al. (1992). Ali et al. (2000) observed that average dry period for crossbred and indigenous cows were 97.2 and 141 days, respectively. Nahar et al. (1992) found that the average dry period for F1 graded Sindhi and Sahiwal as 146 and 127 days, respectively.

Calving interval: The average length of calving interval of crossbred and indigenous cows stood at 419 and 428 days, respectively (Table 4). Statistically non-significant variations existed between the lengths of calving interval crossbred and indigenous cows. Nahar (1987) found that under urban 
conditions, the mean calving interval of Sindhi and Sahiwal cows were 415 and 429 days, respectively. Ali et al. (2000) stated that average length of calving interval of crossbred and indigenous were 653 and 539 days, respectively which contradict to this study.

Service per conception: The average services per conception of crossbred and indigenous cows were 3.10 and 1.95, respectively (Table 4), which were significantly different $(\mathrm{P}<0.01)$. These results were in agreement with Ali et al. (2000) who reported that the service per conception of crossbred and indigenous cows were 3.33 and 1.98, respectively in Gaibandha district.

Calving to first service: Table 4 shows that the average calving to first service for crossbred and indigenous were 116 and 137 days, respectively, which were significantly different $(\mathrm{P}<0.01)$. These results were in agreement with the information of Ali et al. (2000) who observed that average calving to first service for crossbred and indigenous were 124 and 114 days, respectively.

Table 2: Different categories of dairy cattle in the small scale dairy farms

\begin{tabular}{|c|c|c|c|c|c|c|c|}
\hline \multirow[t]{2}{*}{$\begin{array}{l}\text { Type } \\
\text { animal }\end{array}$} & \multicolumn{2}{|c|}{$\begin{array}{l}\text { Indigenous } \\
\text { animal }\end{array}$} & \multicolumn{2}{|c|}{$\begin{array}{l}\text { Crossbred } \\
\text { animal }\end{array}$} & \multirow[t]{2}{*}{$\begin{array}{l}\text { Average No. of } \\
\text { indigenous farm }\end{array}$} & \multirow[t]{2}{*}{$\begin{array}{l}\text { Average No. of } \\
\text { crossbred farm }\end{array}$} & \multirow[t]{2}{*}{$\begin{array}{l}\text { Average No. } \\
\text { of cattle farm }\end{array}$} \\
\hline & No. & $\%$ & No. & $\%$ & & & \\
\hline Milch cow & 19 & 4.87 & 112 & $\begin{array}{l}28.7 \\
2\end{array}$ & 0.63 & 3.74 & 4.37 \\
\hline Dry cows & 7 & 1.79 & 23 & 5.90 & 0.23 & 0.77 & 1.0 \\
\hline Pregnant & 6 & 1.54 & 29 & 7.44 & 0.20 & 0.97 & 1.17 \\
\hline Heifer & 13 & 3.33 & 36 & 9.23 & 0.43 & 1.20 & 1.63 \\
\hline Yearling bull & 5 & 1.28 & 21 & 5.38 & 0.17 & 0.70 & 0.87 \\
\hline Bull calf & 4 & 1.03 & 68 & $\begin{array}{l}17.4 \\
4\end{array}$ & 0.13 & 2.27 & 2.4 \\
\hline Heifer calf & 3 & 0.77 & 44 & $\begin{array}{l}11.2 \\
8\end{array}$ & 0.10 & 1.47 & 1.57 \\
\hline Total & 57 & $\begin{array}{l}14.6 \\
1 \\
\end{array}$ & 333 & $\begin{array}{l}85.3 \\
9 \\
\end{array}$ & 0.89 & 11.12 & 13.01 \\
\hline
\end{tabular}

Highest and lowest milk production: It was revealed from Table 4 that the highest milk production from crossbred and indigenous cows were 10.4 and 2.40 litres/day, respectively, and lowest milk production from crossbred and indigenous cows were 2.29 and 0.72

litres/day, respectively.

Milk yield per lactation: Milk yield per lactation for crossbred and indigenous were 1210 and 358 litres, respectively. The difference in milk production between crossbred and indigenous cows was highly significant $(\mathrm{P}<0.01)$. Similar studies were made by Halim $(1992)$

who found that total milk production per lactation of crossbred and indigenous cows were 800 and 296 litres, respectively.

Lactation period: The average lactation period for crossbred and indigenous cows was 283 and 207 days, respectively, which differ significantly $(\mathrm{P}<0.01)$. Another study made by Halim (1992) who found the length of lactation period for crossbred and indigenous cows were 259 and 228 days, respectively.

Costs of rearing dairy cows in the study area: In this study cost items consisted of feeds, labour, housing, veterinary services, AI and costs of capital that is interest on fixed and operating capital. In the process of raising dairy cows, farmers often concomitantly require to keep calf and heifer in their farm. In such a situation the purpose of costing did not to be realistic to isolate the dairy cows from other animals to the farm business. It is noted that average daily total cost of raising per dairy cow was taka 67.51 in the study area (Table 5). Item wise costs are discussed below. 
Feed cost: Cost of feed included expenses on paddy straw, green grass and concentrate etc. The purchased feeds were valued according to the average prices actually paid for the items. Home supplied feeds were also charge according to the average prices prevailing in the market. Only a few owners produced green grass. Farmers used to feed their cows by using weeds as a substitute of green grass. It is evident from Table 5 that feed cost was the most important component that represents 58.72 per cent of total cost.

Labour cost: Labour was computed as the total cost of labour used for raising dairy cows. Then the total labour cost was converted into per cow per day level. However, it can be noted that on an average labour cost per cow per day amount Tk. 10.00 .

Housing cost: In the study area the farmers used half building and tin shed houses for dairy animals. The cost of housing was calculated by taking into account the depreciation cost, repairing cost and interest of the average value of cattle shed. It was found that on an average housing cost per day per cow was Tk. 2.85 .

Veterinary cost: It was observed that veterinary cost/cow/day was Tk. 5.50. Halim (1992) who found that the treatment cost per lactation of crossbred cows was Tk. 92.00. It was found in this study that the treatment cost was higher for crossbred.

A.I. cost: From the Table 5, it was found that A.I. Cost for a crossbred was Tk. 1.80.

Interest on capital and operating cost: In the present study, the market value of dairy cows was considered as the Capital. The operating capital was calculated on the average variable cost such as feed cost, hired labour cost and veterinary cost. The interest for capital was calculated at the rate of 15 $\%$ per annum. Table 5 shows that the interest on capital (average value of cow operating capital) per day per cow was Tk. 4.22 .

Table 3: Housing system, feeding system, fodder cultivation, breeding system and overall management system of small scale dairy farm

\begin{tabular}{|c|c|c|c|c|}
\hline \multicolumn{2}{|l|}{ Information } & Percentage & Information & Percentage \\
\hline \multirow[t]{9}{*}{ Housing system } & Type of cow shed & & Washing of udder by & \\
\hline & Half building & 10 & Warm water & 43 \\
\hline & Tin shed & 40 & Normal water & 67 \\
\hline & Straw shed & 50 & Dairy equipment & \\
\hline & Pattern of housing & & Traditional & 77 \\
\hline & Open & 80 & Modern & - \\
\hline & Closed & 13 & Semi-modern & 23 \\
\hline & Semi closed & 7 & Preventive register & \\
\hline & Types of feeding system & & Maintained & 7 \\
\hline \multirow[t]{9}{*}{ Feeding System } & Stall & 63 & Not maintained & 93 \\
\hline & Stall + Grazing & 37 & Storage of milk & \\
\hline & Grazing & - & Freezing & 17 \\
\hline & Others & - & Not stored & 83 \\
\hline & Types of calf feeding & & Isolation of sick cattle & \\
\hline & Suckling & 100 & Kept isolated & 7 \\
\hline & Bottling & - & Not kept isolated & 93 \\
\hline & Milk starter & - & Causes of disposal & \\
\hline & Types of grasses & & Unproductive & 30 \\
\hline \multirow{4}{*}{$\begin{array}{l}\text { Fodder } \\
\text { cultivation }\end{array}$} & Napier & 20 & Infertility & 70 \\
\hline & Maize & 40 & Labor type & \\
\hline & No grass cultivation & 40 & Skilled & 7 \\
\hline & $\begin{array}{l}\text { Constraints of fodder } \\
\text { cultivation }\end{array}$ & & Non skilled & 93 \\
\hline
\end{tabular}




\begin{tabular}{|c|c|c|c|c|}
\hline & Scarcity of land & 43 & Place of selling & \\
\hline & Scarcity of seed/cutting & 50 & Broker & 17 \\
\hline & Lack of know hedge & 7 & Local market & 13 \\
\hline & Types of roughage & & Sweet maker & 20 \\
\hline & Treated & 20 & Home service & 20 \\
\hline & Untreated & 40 & Own selling center & 30 \\
\hline & Breeding methods & & Disposal of manure & \\
\hline \multirow[t]{4}{*}{ Breeding system } & AI & 87 & Sold out & 73 \\
\hline & AI and natural & 13 & As manure & 20 \\
\hline & Natural & - & As fuel & 7 \\
\hline & Milking & & Sanitizer used & \\
\hline \multirow{18}{*}{$\begin{array}{l}\text { Management } \\
\text { system }\end{array}$} & Hygienically & 53 & Phenyl & 70 \\
\hline & Unhygienically & 47 & Potas & 23 \\
\hline & Milking system & & Phenyl+Potas & 50 \\
\hline & Manual & 100 & Bleaching powder & 10 \\
\hline & Mechanical & - & Treatment by & \\
\hline & Water source & & Veterinary surgeon & 90 \\
\hline & Water supply & 77 & Locally trained person & 10 \\
\hline & Tube well & 13 & $\begin{array}{l}\text { Vaccination } \\
\text { dewarming }\end{array}$ & \\
\hline & Pond & 10 & Black quarter & 70 \\
\hline & Water supply & & Hemorrhagic Septicemia & 60 \\
\hline & Adequate & 80 & FMD & 100 \\
\hline & Inadequate & 20 & De-worming & 100 \\
\hline & Cleaning done by & & Complexity of bank loan & \\
\hline & Pipe & 77 & Yes & 80 \\
\hline & Bucket & 23 & No & 20 \\
\hline & Cleaning & & & \\
\hline & Regularly & 72 & & \\
\hline & Irregularly & 28 & & \\
\hline
\end{tabular}

Returns from rearing crossbred dairy cows/day/cow in the study area: The return from diary cow consisted return from milk yield, cowdung, empty gunny bag and return from use of animal for other purposes. All these items were considered in computing the gross return from dairy cows.

Table 4: Productive and reproductive performances of dairy cows

\begin{tabular}{llll}
\hline Parameters & Crossbred & Indigenous & $\begin{array}{l}\text { Level of } \\
\text { Significance }\end{array}$ \\
\hline Dry period (days) & $98.5 \pm 16.9$ & $140 \pm 10.4$ & $* *$ \\
Calving interval (days) & $419 \pm 11$ & $428 \pm 24.7$ & NS \\
Service per conception & $3.10 \pm 0.82$ & $1.95 \pm 0.44$ & $* *$ \\
Calving to first service (days) & $116 \pm 25.8$ & $137 \pm 7.76$ & $* *$ \\
Highest milk production (Li/d) & $10.4 \pm 1.79$ & $2.40 \pm 0.51$ & $* *$ \\
Lowest milk production (Li/d) & $2.92 \pm 0.72$ & $0.72 \pm 0.25$ & $* *$ \\
Milk yield (Li/lactation) & $1210 \pm 57.8$ & $358 \pm 27.1$ & $* *$ \\
Lactation period (days) & $283 \pm 14.5$ & $207 \pm 13.7$ & $* *$ \\
Average milk production (Li/lactation) & $4.27 \pm 0.52$ & $1.78 \pm 0.13$ & $* *$ \\
\hline$* *=$ Significant at 1\% level of probability. NS = Non significant &
\end{tabular}


Table 5: Costs of rearing crossbred dairy cows per days per cow in the study area

\begin{tabular}{lll}
\hline Items & Quantity (kg) & Total cost (Tk.) \\
\hline Feed cost & 7 & \\
Paddy straw & 12 & 5.25 \\
Green grass & 3.75 & 7.20 \\
Concentrates & - & 27.19 \\
Labour cost & - & 10 \\
Housing cost & - & 2.85 \\
Veterinary cost & - & 5.50 \\
A.I. cost & - & 1.80 \\
Others & - & \\
Transport & - & 1.50 \\
Tools and equipments & - & 2 \\
Interest on capital & & 4.22 \\
Total & & 67.51 \\
\hline
\end{tabular}

Table 6: Returns from rearing per dairy cow per day in the study area

\begin{tabular}{lllll}
\hline Return items & Unit & Quantity & Price (Tk/liter) & Total (Tk.) \\
\hline Milk & Liter & 4.27 & 18 & 76.86 \\
Return from calf & - & - & 3.50 & \\
Value of cowdung & - & 5 & - & 4.50 \\
Empty gunny bag & Tk. & - & - & 0.30 \\
Total & - & - & - & 85.16 \\
Gross cost & - & - & - & 67.51 \\
Net return & - & - & - & 17.65 \\
Cost benefit ratio & & & & $1: 1.26$ \\
\hline
\end{tabular}

Returns from milk, cowdung and calf: It is evident from Table 6 that on an average returns from milk were Tk. 76.9 per day in the study area. The table reveals that on an average per day returns from cowdung was Tk.4.50. Value of calf was considered as the approximate market value of calf after a year. Although most of the farmers did not sell their calves but they were able to estimate in approximate local market value of the calves possessed by them, which was considered as the value of the calves. However, from the annual returns per day were calculated on per day basis (Table 6) and an average per day return from cow was Tk. 3.50.

Returns from empty gunny bag: Returns from empty gunny bag per cow was calculated by taking average income from empty gunny bag. Return from empty gunny bag was Tk. 0.30 per day basis.

Net return and Benefit Cost Ratio (BCR) from dairy cows: Deducting all costs from gross returns arrived at net return from dairy cows. Table 6 reveals that daily net return per dairy cow was Tk. 17.65 and Cost Benefits Ratio of dairy enterprises, which is on an average 1: 1.26 .

Table 7: Economics study

\begin{tabular}{ll}
\hline Condition & Percentage \\
\hline Profitable & 70 \\
Less Profitable & 20 \\
Balance & 10 \\
\hline
\end{tabular}


Most of the farmers (70\%) said that dairy farming was profitable, 20\% said less profitable and 10\% said balance. From the above discussion, it may be concluded that the present management condition of small dairy farms in Mymensingh district is more or less traditional and the productive and reproductive performance of crossbred cows was better than that of indigenous cows. Most of the farmers believe that dairy farming is a profitable enterprise and can be more profitable if Government gives support on feed cost, marketing, loan and management training. The following recommendations may be suggested as broad guidelines for successful operation of small dairy farm in the study area:

1. Private sectors should be given priority to establish small-scale cattle feed industry providing financial support by the government and these feed industries will sell the feed to the registered dairy farms in a fixed price recommended by government time to time.

2. The shortage of feeds and fodder may partially be overcome by introducing HYV fodder cultivation. The government and non-government organizations should play a vital role in disseminating the technology of HYV fodder cultivation in rural areas.

3. Good quality semen should be preserved centrally and distribute to the AI centres for further use as and when required basis.

4. Veterinary care and services to the small farm owners should be strengthened.

5. Regular short training programme on different management of dairying should be arranged for the farm owners and short term institutional loan or credit should be given to actual farm owners and to be checked regularly.

6. The price of milk should be fixed within a reasonable level and milk-marketing system should be improved through the intervention by the government.

\section{REFERENCES}

Ali, M.H., M.A.S. Khan, M.N. Islam, M.K.I. Khan, M.M. Rashid and M.J. Khatun, 2000. Comparative performance study on the crossbreeds and indigenous cows under small holder dairy farming. Pak. J. Bio. Sci., 3: 795-798.

FAO., 1994. Production Year Book Rome, Italy.

Halim, M.A., 1992. A comparative economic analysis of local and crossbred dairy cows in a selected area of Dhaka district. M.Sc. Thesis, Department of Agricultural Economics, Bangladesh Agricultural University, Mymensingh, Bangladesh.

Hossain, Z.M.A., S.M.J. Hossain, M.M. Rashid, N. Sultana and M.H. Ali, 2004. Study on the present management condition of private dairy farm at Rangpur Sadar Thana in Bangladesh. J. Biol. Sci., 3.

Islam, M.A., 1992. A comparative economic analysis of milk cows and buffaloes in two selected village of Mymensingh district in Bangladesh. M.Sc. Thesis. Department of Agricultural Finance, Bangladesh Agricultural University, Mymensingh, Bangladesh.

Jabbar, M.A. and S.K. Raha, 1984. Consumption pattern of Milk and Milk products in Bangladesh. The Bangladesh. J. Agri. Eco., VII (2): 29-44.

Kabir, M.A., 1995. An economic study of subsidized private dairy farming in selected area of Bangladesh. M.Sc. Thesis Department of Agricultural Economic, Bangladesh Agricultural University, Mymensingh. Bangladesh, pp: 129-134.

Khan, M.S., 1996. study on status of private dairy Farms among different District in Bangladesh. M.Sc. Thesis. Department of Dairy Science. Bangladesh Agricultural University, Mymensingh, Bangladesh.

Nahar, N., 1987. A comparative study on the performances of F1 crossbred progenies on Farm an Urban conditions. M.Sc. Thesis, Department of Animal Breeding and Genetics. Bangladesh Agricultural University, Mymensingh.

Nahar, T.N., M. Islam and M.A. Hasnath, 1992. A comparative study on the performance of F1 crossbred cows under rural conditions. Asian-Aust. J. Anim. Sci., 5: 435-438.

Steel, R.G.D. and J.H. Torrie, 1980. Principles and procedures of statistics; A biometrical approach. 2nd. Ed. McGraw-Hill, Singapoe. 